\title{
INDIKASI PENCITRAAN DALAM UPACARA ADAT REBO PUNGKASAN DI WONOKROMO PLERET BANTUL YOGYAKARTA
}

\author{
Galih Puspita Karti \\ galihpuspitakarti@gmail.com
}

\begin{abstract}
Abstrak
Penelitian mengenai indikasi pencitraan dalam upacara adat Rebo Pungkasan bertujuan sebagai media introspeksi masyarakat agar selalu merawat nilai-nilai keaslian budaya dan spiritualnya. Kesadaran tentang upacara adat sebagai media untuk berhubungan dengan segala isi alam semesta dan Tuhan Yang Maha Esa perlu dibangunkan kembali guna menjadi pembatas agar tidak terjebak dalam sebuah pencitraan semata. Metode penelitian kualitatif dipilih untuk memperoleh segala informasi tentang upacara adat Rebo Pungkasan. Pada akhirnya sebuah indikasi pencitraan ditemukan dalam ritual tersebut. Pencitraan sudah merajalela dalam area ritual. Pada satu ruang lingkup upacara adat Rebo Pungkasan, pencitraan dapat dilihat jelas dalam kepalsuan lemper Boga Wiwaha yang dijadikan sebagai persembahan/caos dhahar. Wujud lemper dilebih-lebihkan dengan ukuran panjang antara dua meter dan diameter sekitar setengah meter supaya menarik untuk dijadikan sebuah ikon. Segalanya dikemas manis dan menarik seperti pada iklan di televisi, orasi pada kampanye, aktivitas dalam sosial media, dan sebagainya. Hampir dibalik itu semua terdapat sesuatu yang dilebih-lebihkan, kepalsuan bahkan kebohongan yang disembunyikan. Sesuatu yang disajikan/ditawarkan belum tentu sesuai dengan kenyataan yang terjadi. Sebuah pencitraan sama halnya dengan sebuah topeng yang menjadi penutup citra yang sesungguhnya.
\end{abstract}

Kata Kunci : pencitraan, upacara adat, rebo pungkasan, lemper boga wiwaha

\begin{abstract}
Research on the imaging indication ceremonial Rebo Pungkasan intended as a medium of introspection people to always take care of the values of cultural and spiritual authenticity. Awareness about the ceremonies as a medium to get in touch with all the contents of the universe and God Almighty needs to be woken up again to be a barrier to not get stuck in an imaging alone. Qualitative research method was chosen to obtain any information about Rebo Pungkasan ceremonies. In the end an imaging indication is found in the ritual. Imaging is already rampant in the ritual area. In the scope of traditional ceremonies Rebo Pungkasan, imaging can be seen clearly in falsehood donuts Boga Wiwaha used as offerings / caos Dhahar. Exaggerated form of donuts with a length between two meters and a diameter of about half a meter so interesting to be an icon. Everything is packaged sweet and charming as the ads on TV, speeches on the campaign, the activity in the social media, and so on. Almost behind it all there is something exaggerated, even falsity lies hidden. Something that presented / offered not necessarily correspond with the reality of the matter. An imaging as well as a mask that became the cover image of the real thing.
\end{abstract}

Keywords : imaging, ceremony, rebo pungkasan, lemper boga wiwaha 


\section{Pendahuluan}

Jika kita menonton atau meneliti banyak upacara, jangan heran bila kita kemudian merasa seperti sedang menonton teater atau seni pertunjukan. Ada sosok yang berperan seolaholah ia adalah seseorang yang paling pantas berkuasa, sosok yang seolah-olah dikuasai, dan sosok yang melawan atau beriktiar untuk merebut kekuasaan dari yang lain. Akan tetapi semua itu cuma peran "seolah-olah" dan tidak harus sesuai dengan realita. Semua itu hanya pertunjukan yang simbolik (Lastoro, 2007:93). Artinya bahwa, dalam ritual sebuah estetika juga tetap dibutuhkan. Wujud sebuah upacara tidak lah lepas dari pencitraan.

Dusun Wonokromo Pleret, Bantul, Yogyakarta adalah daerah yang memiliki agenda rutin setiap tahunnya untuk mengadakan upacara adat tolak bala. Upacara tersebut bernama upacara adat Rebo Pungkasan, Rebo dalam bahasa Indonesia berarti hari Rabu dan Pungkasan yang berarti terakhir. Upacara diselenggarakan menjelang hari Rabu terakhir bulan Sapar, tepatnya pada hari Selasa sebelumnya. Sapar adalah salah satu nama bulan dalam kalender Sultan Agung. Kalender tersebut terdiri dari bulan Sura, Sapar, Mulud, Bakda Mulud, Jumadilwal, Jumadilakhir, Rejeb, Ruah, Pasa, Syawal, Dulkangidah dan Besar, upacara ini berdiri sejak tahun 1755.

Orang Jawa Kejawen memberi sesajen atau caos dahar yang dipercaya dapat menggelakkan kejadian-kejadian yang tidak diinginkan dan mempertahankan batin dalam keadaan tenang. Sesajen yang digunakan biasanya terdiri dari nasi dan aneka makanan lain, daun-daun, bunga, serta kemenyan ( $\mathrm{MH}, 2012:$ 20). Pada upacara adat Rebo Pungkasan, Caos dahar yang dipersembahkan adalah gunungan dari hasil panen masyarakat dan sebuah lemper raksasa dengan panjang dua meter.

Lemper raksasa merupakan ikon utama dalam upacara adat Rebo Pungkasan yang dinamai Lemper Boga Wiwaha. Lemper adalah panganan dibuat dari nasi pulut/ketan, dibungkus dengan daun pisang (Poerwadarminta, 2007 : 688). Biasanya berisi cincangan daging dengan dua tusuk lidi sebagai pengunci di bagian dua sisi pinggirnya.

Menurut masyarakat Wonokromo, lemper memiliki makna dan arti simbolis yaitu untuk mencapai suatu kesempurnaan hidup manusia harus membersihkan segala yang tidak baik dan sifat buruk. Ibarat dalam makanan lemper orang yang ingin menikmati lezatnya lemper harus membuang kulit lemper yang dibuat dari daun pisang. Kemudian orang akan dapat merasakan ketan hingga lezatnya daging cincang.

Hanya saja pada beberapa tahun terakhir ini khusus lemper tersebut tidak lagi diperbolehkan dirayah oleh para pengunjung yang datang, walaupun sudah ada gunungan yang bisa dirayah tetapi lemper adalah sebuah ubo rampe yang paling diharapkan masyarakat untuk bisa dirayah seperti tahun-tahun sebelumnya.

Dipercaya bahwa di dalam ubo rampe yang ada dalam upacara adat merupakan sebuah berkah bagi masyarakat yang diyakini memiliki nilai magis yang kuat. Berawal dari fenomena tersebut peneliti tertarik untuk meneliti lebih lanjut tentang upacara adat Rebo Pungkasan. Mengapa lemper tidak diperbolehkan dirayah merupakan pertanyaan paling mendasar yang mendorong untuk melakukan sebuah penelitian, padahal lemper adalah salah satu ubo rampe yang ditunggu-tunggu oleh masyarakat yang datang. 


\section{Sekilas Tentang Upacara Adat Rebo Pungkasan}

Unsur dalam upacara adat Rebo Pungkasan adalah berdoa, berprosesi atau berpawai, serta rayahan atau makan bersama makanan yang telah disucikan dengan doa. Satu hari sebelum upacara adat berlangsung masyarakat Wonokromo melakukan doa bersama di Masjid Karanganom. Doa-doa dilakukan secara islami diantaranya membaca Al-Fatihah, Yasin, Wiridan, doa Sapu Jagad serta doa untuk peringatan Maulid Nabi yang juga dipanjatkan karena upacara adat berdekatan dengan Maulid Nabi.

Satu hari setelahnya masyarakat Wonokromo melakukan prosesi arak-arakan lemper Raksasa Boga Wiwaha beserta gunungan dari hasil panen masyarakat sekitar. Arakarakan tersebut diiringi oleh beberapa kelompok Bregadha. Barisan bregadha diawali dengan beberapa orang yang berperan sebagai tokoh dalam sejarah Rebo Pungkasan. Misalnya Sultan Agung, Kyai Welit, dan sebagainya. Beberapa ekor kuda menjadi tunggangan tokoh-tokoh tersebut. Sebagai bregadha awal biasanya diawali dengan prajurit Lombok Abang, setelahnya baru yang ditampilkan oleh masyarakat daerah Wonokromo.

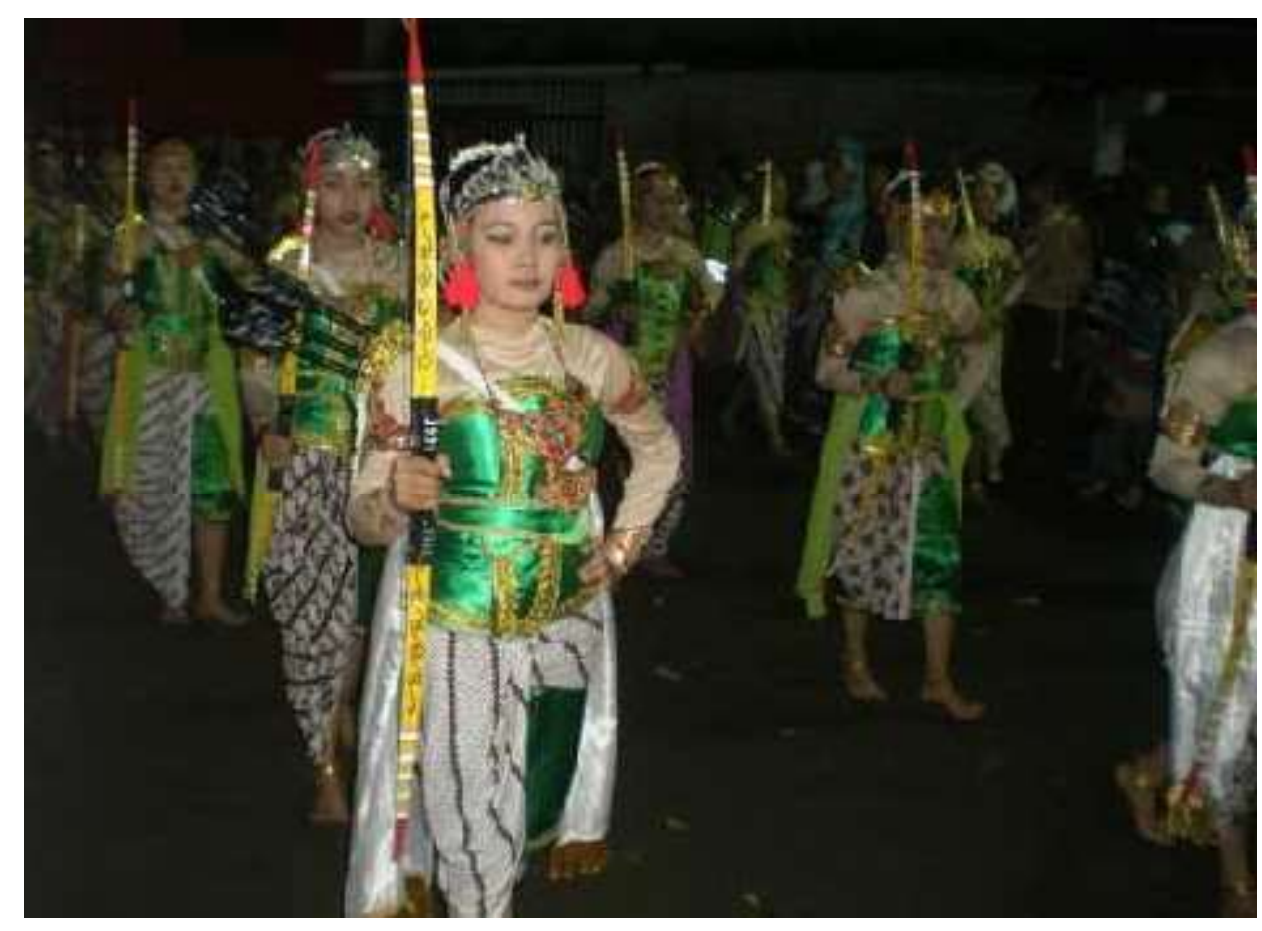

Gambar 1. Salah satu bregadha Putri yang ikut prosesi arak-arakan (Doc. Galih, 2014) 
Setiap kelompok bregadha merupakan perwakilan dari beberapa pedukuhan yang ada di kelurahan Wonokromo. Arak-arakan biasanya dimulai pada pukul 9 malam. Perjalanannya arak-arakan dari masjid Karanganom hingga Pendhapa Kelurahan Wonokromo kurang lebih selama 45 menit.

Puncak acaranya ada di pendhapa kelurahan Wonokromo. Penonton mendatangi kelurahan Wonokromo, tempat lemper raksasa akan dibelah. Selagi menunggu kedatangan arak-arakan lemper raksasa Boga Wiwaha diadakan sebuah pertunjukan, bisa disebut sebagai pra acara upacara adat. Salah satu pertunjukannya adalah pementasan Hadroh yang ditampilkan oleh masyarakat setempat. Pementasan dilakukan beberapa jam sebelum berlangsungnya upacara adat. Daerah Wonokromo merupakan daerah yang terkenal dengan masyarakat yang kuat dengan agama Islam, sehingga salah satu kesenian yang menjadi andalan adalah pementasan hadroh.

Aspek pertunjukan yang penting dalam hadroh adalah syair-syairnya yang berisi pujian-pujian islami (shalawat nabi) yang didendangkan dengan alat musik rebana. Biasanya setiap kelompok hadroh terdiri dari tujuh sampai sepuluh orang dengan posisi pola lantai duduk yang berjajar. Durasi dalam setiap penyaji hadroh kurang lebih tujuh sampai sepuluh menit.

Busana yang digunakan oleh pemain biasanya berupa celana panjang/sarung, baju koko dan kopiah. Hanya saja semakin tahun semakin berkembang, visualisasi tentang kostum mulai diperhatikan. Beberapa kelompok kesenian sudah mulai menggunakan sragam yang difungsikan hanya untuk pementasan tersebut. Kelompok hadroh dari masyarakat sekitar ditampilkan pada tempat tersebut. Pementasan hadroh sudah menjadi rangkaian acara yang harus dilakukan untuk menunggu lemper raksasa Boga Wiwaha yang sedang diarak dari masjid Karanganom ke kelurahan Wonokromo.

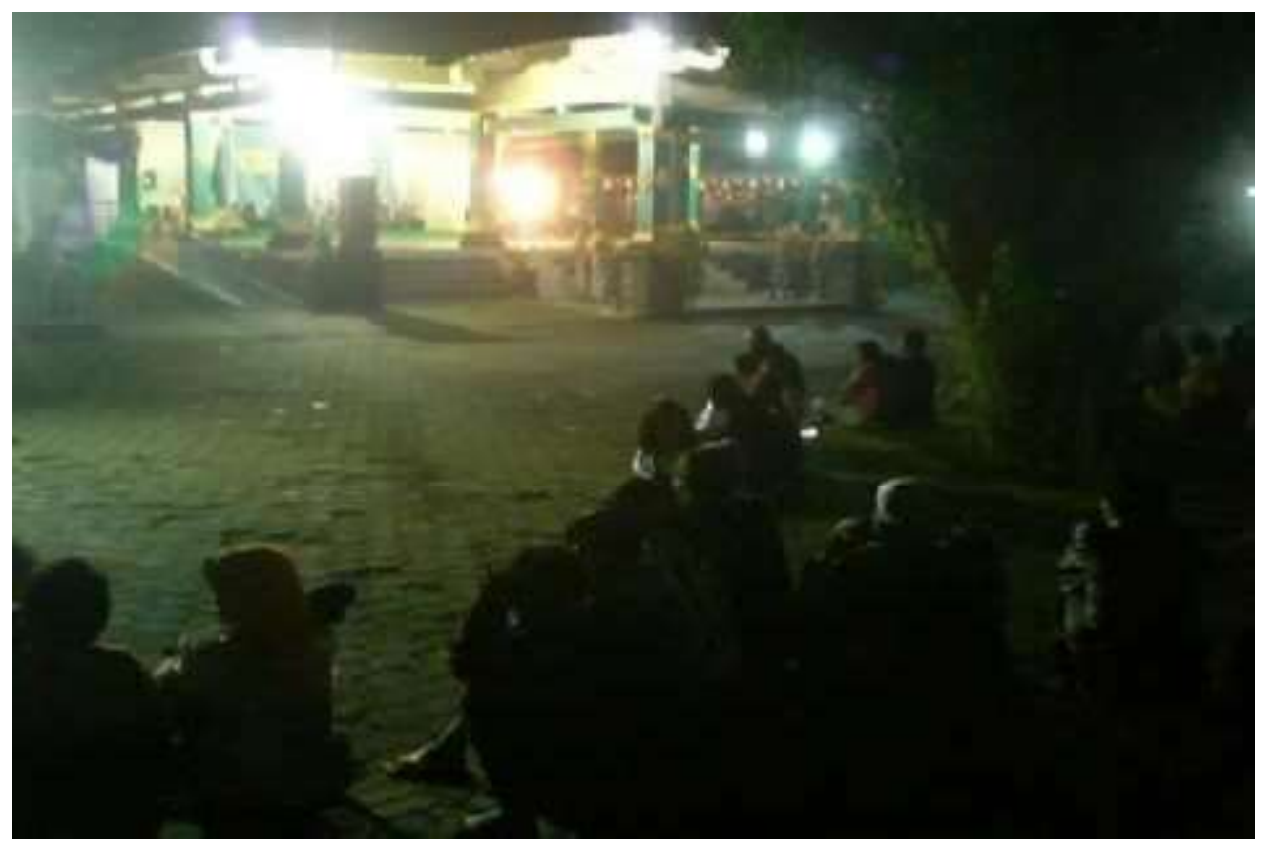

Gambar 2. Suasana Pendhapa Wonokromo saat para penonton menunggu kedatangan Lemper Raksasa. (doc. Galih, 2014) 
Selain Hadroh terdapat juga pencak silat yang berasal dari komunitas daerah Wonokromo. Pencak silat sengaja dikemas untuk pertunjukan, sehingga konsep ruang, waktu dan tenaga mulai sedikit diterapkan. Pencak silat dipertunjukan dalam tempat yang sama dengan pementasan Hadroh. Runtutan acara terakhir sebelum acara inti biasanya adalah pembagian hadiah untuk para pemenang lomba. Pada tahun 2008 lomba yang diadakan adalah turnamen bulu tangkis, lomba lukis mewarnai, pidato bahasa Jawa, dan membuat peningset. Pada tahun 2015 ini juga diadakan lomba band. Perlombaan dilakukan beberapa hari sebelum puncak upacara adat Rebo Pungkasan. Kadangkala diadakan juga sebuah pengajian akbar di tempat tersebut, pengajian dilakukan satu hari sebelum puncak acara.

Seperti yang sudah dijelaskan pada bagian atas, bahwa salah satu fungsi pertunjukan tersebut guna menyongsong kedatangan lemper raksasa Boga Wiwaha yang diarak oleh beberapa kelompok bregadha dengan rias busana yang beraneka macam. Maka, setelah para bregada memasuki area pendhapa, segala pertunjukan yang terdapat di Pendhapa Kelurahan Wonokromo harus diberhentikan. Lemper raksasa Boga Wiwaha di arak hingga diatas pendhapa. Sebelum rayahan, lemper raksasa Boga Wiwaha didoakan terlebih dahulu. Doanya cukup menarik, salah seorang yang merupakan tokoh masyarakat melantunkan sebuah tembang yang berisi doa-doa, harapan. Setelahnya, lemper raksasa Boga Wiwaha dibelah menjadi dua bagian. Hal tersebut merupakan puncak acara upacara adat Rebo Pungkasan. Pada tahun 2015, hanya gunungan yang boleh dirayah oleh penonton, ada juga beberapa panita yang sengaja melempar lemper-lemper kecil/lemper ukuran normal ke arah penonton, sedangkan Lemper Raksasa Boga Wiwaha diamankan oleh panitia upacara.

Salah satunya agenda yang dapat menarik khalayak umum adalah pasar malam yang diadakan dua minggu sebelumnya. Pasar malam diadakan tepat di lapangan depan kelurahan Wonokromo (lokasi upacara adat berlangsung). Lokasi tersebut mulai dipadati oleh pendatang kira-kira pada pukul 15.00-22.00 WIB. Sama halnya seperti sekaten ataupun pasar malam lainnya, tempat tersebut dipenuhi dengan para penjual baju, permainan-permainan dan makanan-makanan yang seolah-olah menjadi ciri khas dari pasar malam pada umumnya misalnya arum manis, tetapi ada hal yang sedikit berbeda dari pasar malam Rebo Pungkasan ini yaitu banyaknya penjual mainan dari tanah liat yang berjajar di pinggir jalan raya. Seperti wajan, gelas, lepek, anglo, piring, dll. Barangbarang tersebut dibuat dengan tanah liat dan dalam ukuran minimalis karena fungsinya hanya sebagai mainan anak-anak. Orang Jawa menyebutnya pasaran.

Hal tersebut yang membuat beda pasar malam yang ada di Wonokromo dengan pasar malam lainnya, mainan-mainan dari tanah liat yang diproduksi oleh masyarakat sekitar menjadi suatu ciri khas dari pasar malam yang ada di Wonokromo. Rangkaian acara dari Rebo Pungkasan, dari pementasan, perlombaan, pengajian, arak-arakan, hingga pasar malam merupakan gagasan dari karangtaruna yang didukung oleh pamong desa setempat. 


\section{Metode Penelitian}

Metode penelitian kualitatif dipilih untuk memperoleh data yang dibutuhkan. Dilakukan sebuah observasi pada objek yang dipilih. Pada penelitian ini dipilih Upacara Rebo Pungkasan sebagai objek utamanya. Penelliti mendatangi langsung upacara tersebut. Bahkan beberapa waktu sebelum upacara dimulai dilakukan pengamatan-pengamatan pada proses pembuatan lember dan berbagia uborampe. Pada penelitian ini, peneliti mencoba berbaur dengan pelaksanan kegiatan, perangkat desa, dan penonton.

Setelah usai, dilakukan wawancara dengan seorang narasumber. Dipilih seorang narasumber yang mengerti dan memahami tentang upacara tersebut. Wawancara dilakukan secara tidak terstruktur, sehingga informasi yang dicari berkembang ketika menyaksikan upacara secara langsung.

\section{Temuan dan Pembahasan}

Kesadaran atas rasa memiliki seni dan tradisi adalah salah satu pendidikan yang ditanamkan sejak kecil oleh keluarga. Kebetulan pada saat duduk di bangku Sekolah Dasar (SD), peneliti beserta keluarga pindah rumah dengan lokasi yang cukup dekat dengan daerah Wonokromo. Saat itu mulai dikenalkan dengan upacara adat Rebo Pungkasan. Beberapa kali mengunjungi upacara adat Rebo Pungkasan, hingga dewasa ini disadari kejanggalan-kejanggalan yang terjadi dalam upacara adat tersebut. Sebagai masyarakat yang dilahirkan dalam lingkup satu kabupaten yaitu Bantul, peneliti merasa terusik dengan kejanggalan-kejanggalan yang terjadi.

Semakin lama terjadi perubahan fungsi pada upacara adat Rebo Pungkasan. nilai kesakralan/spritual dan agungnya upacara adat semakin lama semakin terkikis dan tergantikan dengan euforia pasar malam, pawai, ataupun beberapa pertunjukan yang disajikan untuk mengisi kekosongan waktu saat menunggu kedatangan lemper raksasa yang sedang diarak.

Pada tahun 1950, panjang lemper hanya sekitar setengah meter, tetapi semenjak upacara adat dipindahkan lokasi dan diadakan pawai ukuran lemper diperbesar dengan panjang kurang lebih dua meter dengan diameter setengah meter. 


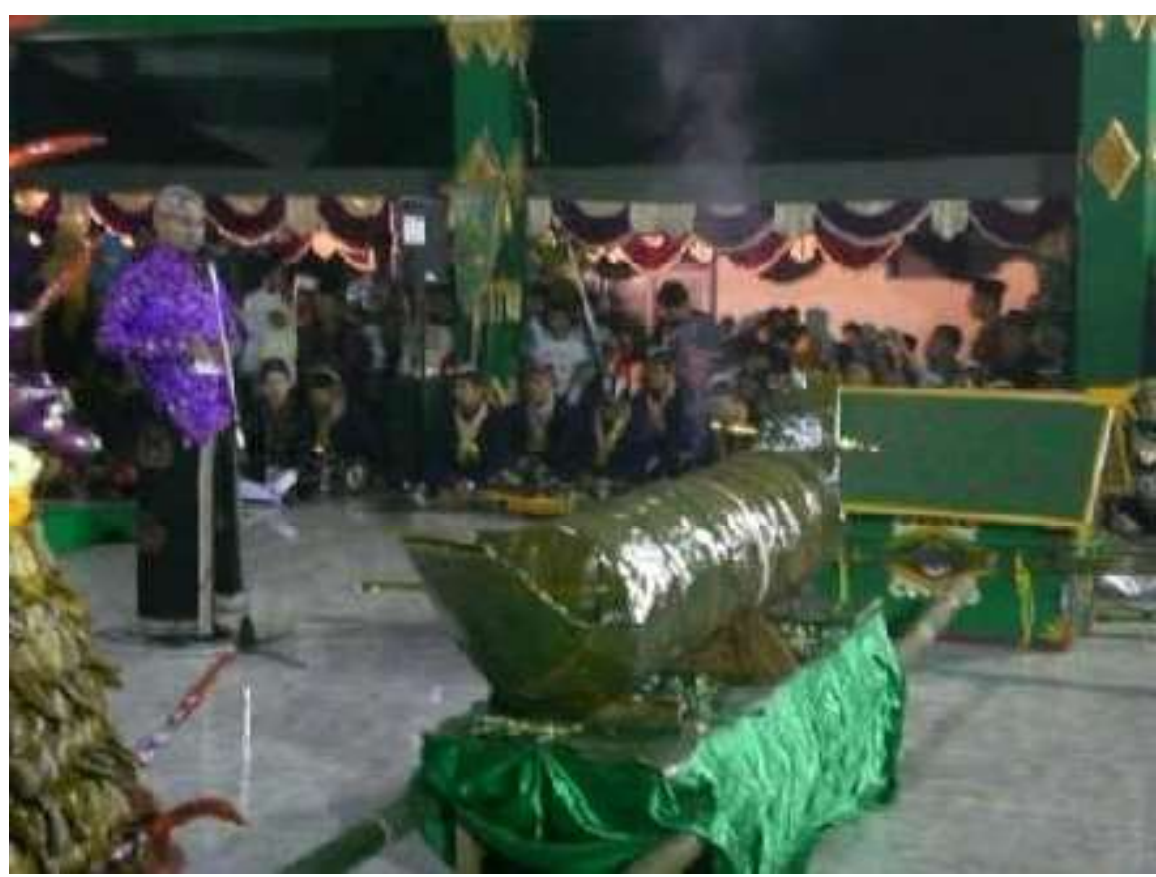

Gambar 3. Lemper Raksasa Boga Wiwaha dengan panjang 2 meter dan lebar setengah meter.

Lemper tersebut merupakan ikon upacara Adat Rebo Pungkasan. (doc. Bangkit, 2014)

Menurut salah satu perangkat desa Wonokromo, lemper raksasa yang menjadi ikon ternyata hanya sebuah replika yang dibuat untuk mendukung upacara adat. Beliau mengatakan bahwa :

."Kalau ada lemper besar itu kan sebenernya replika aja Mbak.

Dalamnya kurungan disambungke di tengahnya ada tempat itu yang isinya sekitar sepuluh kilo lemper dibikin kecil-kecil gitu tetapi ditutup dengan tutup yang.. anu.. apa namanya jadah atau ketan gitu biar kelihatan besar ditempukke gitu jadi tengahnya kalau diiris kayaknya bener to, padahal sini ini kosong Mbak. Adanya ditengah itu"..... \{Ahmad Asyuri (41) 2015, diizinkan dikutip\}

Suatu upacara diadakan sebagai hubungan antara manusia dengan alam secara vertikal atau horizontal. Ketidakharmonisan alam misalnya panen gagal, gempa bumi, banjir wabah penyakit, dan lain sebagainya dimungkinkan karena kurangnya hubungan baik antara alam dan manusia itu sendiri. Sehingga, upacara yang dilakukan dimaksudkan untuk mengembalikan kebaikan alam semesta dan mewujudkan suatu kerjasama yang baik antara keduanya. Hal tersebut sebagai tujuan dilakukannya upacara adat, yang seharusnya juga menjadi tujuan dilangsungkannya Rebo Pungkasan. Keselamatan masyarakat dari musim pageblug yang konon katanya membuat banyak warga Wonokromo meninggal dunia menyadarkan masyarakat bahwa alam memang butuh untuk dihormati. Sangat terkesan ironis ketika pada kenyataanya dibalik makna filosofisnya yang begitu dalam, lemper yang dipersembahkan hanya sebuah replika. 
Lemper raksasa yang diagung-agungkan oleh ribuan masyarakat seolah-olah hanya sebuah kebutuhan pariwisata. Segala sesuatu dibuat semenarik mungkin tanpa memperdulikan lagi akan nilai dan maknanya. Padahal sesunguhnya lemper adalah sesajen utama yang dipersembahkan sebagai wujud rasa syukur dan sarana memohon perlindungan kepada penguasa alam makrokosmos.

Tidak hanya pada waktu tertentu, biasanya suatu ritual dilakukan pada tempattempat khusus. Upacara adat Rebo Pungkasan awalnya dilakukan di sebuah tempuran antara kali Opak dan kali Gajah Wong. Selain lokasinya dekat dengan masjid, nilai sejarah merupakan alasan mengapa tempuran menjadi tempat berlangsungnya upacara adat. Akan tetapi pada tahun 1950, upacara adat mulai dipindahkan di kelurahan Wonokromo dengan alasan bahwa semakin banyak orang yang mengunjungi upacara adat termasuk beberapa pedagang dan pasar malam yang didirikan didekat tempuran. Masuk akal ketika dilogikakan, tetapi dengan memindahkan tempat ternyata menyebabkan kelunturan atas nilai-nilai yang terkandung semakin menjadi. Ide-ide kreatif semakin tidak terkontrol. Pasar malam, turnamen dan beberapa pentas seni diagendakan dengan sistem event organiser untuk mengurus segala acara. Tujuan upacara adatpun semakin lama semakin tergeser. Kejanggalan lain sangat terasa, politik ekonomi sepertinya mulai menyelinap di dalamnya.

Pada tahun 2014 didapati sebuah informasi tentang sejarah upacara adat Rebo Pungkasan yang sampai sekarang masih belum jelas mengenai kebenarannya. Pada momentum upacara, seseorang yang berperan sebagai pemangku adat menyampaikan semacam pidato yang menjelaskan bahwa sejarah Rebo Pungkasan memiliki beberapa macam versi dan tidak dapat dipastikan mana yang benar dan mana yang salah.

Sejarah Rebo Pungkasan memang masih simpang siur karena terdapat dua versi cerita. Cerita pertama mengenai seorang Kyai yang dapat menyembuhkan seluruh masyarakat Wonokromo yang saat itu terkena berbagai macam penyakit, sedangkan cerita pada versi kedua mengenai pertemuan Sultan Agung dengan Kanjeng Ratu Kidul di tempuran kali Opak dan kali Gajah Wong yang terdapat di Wonokromo. Artinya bahwa cikal bakal upacara adat itu sendiri saja ternyata kurang dipahami dengan baik, oleh pemangku adat sekalipun. Tidak salah apabila rasa penghormatan kepada leluhur semakin hari semakin luntur. Apalagi panitia penyelenggaranya adalah organisasi karangtaruna. Kepercayaan diserahkan sepenuhnya kepada para pamuda untuk menjalankan upacara adat. Sedangkan selera muda menjadi pengaruh besar dalam kemasan upacara adat secara keseluruhan.

Upacara telah dianggap sebagai bentuk ekspresi kolektif bagi tiap-tiap komunitas dan dengan itulah mereka mewujudkan eksistensinya (Lastoro, 2007: 56). Apabila membicarakan kepentingan eksistensi, kemungkinan upacara adat Rebo Pungkasan dapat dikatakan salah satunya. Jadwal rutin dengan berbagai rangkaian agenda serta adanya dana dari pemerintah seolah-olah mendorong masyarakat untuk membuat sebuah 'pertunjukan' Rebo Pungkasan, bukan ritual. Kekhawatirannya adalah masyarakat tidak memiliki pondasi atau landasan nilai yang kuat, sehingga yang mereka lakukan setiap tahunnya hanya terkesan sebagai agenda rutin yang wajib dilanjutkan ke generasigenerasi berikutnya guna meningkatkan kwalitas ekonomi masyarakat setempat. Lalu bagaimana dengan masyarakat yang datang dengan tujuan benar-benar ingin ngugemi 
(murni melakukan ritual) upacara adat tersebut. Saya berkesempatan berinteraksi dengan seorang pengunjung yang setiap tahunnya datang mengunjunginya. Kesadaran atas rasa memiliki yang menjadi alasannya untuk selalu menyaksikan. Rasa empati yang ditanamkan terhadap upacara adat yang membuat beliau sadar akan kewajiban melestarikannya. Upacara adat merupakan salah satu sarana beliau untuk bersyukur kepada Tuhan dan alam semesta. Di dalam benak saya terlintas, apakah pantas orangorang seperti itu dibohongi dengan sebuah pencitraan yang diciptakan dalam upacara adat.

\section{Pencitraan Pada Upacara Adat Rebo Pungkasan}

Pencitraan merupakan salah satu cara agar citra menjadi baik/bagus di mata publik. Fenomena kejanggalan yang terjadi, dapat diindikasikan bahwa terdapat unsur pencitraan dalam upacara adat Rebo Pungkasan. Sebuah citra seolah-olah menjadi sesuatu yang sangat penting dari pada pertahanan mengenai unsur nilainya. Rekayasa dilakukan dengan sedemikian rupa guna mencari dan meningkatkan citra yang positif di mata banyak orang.

Replika lemper, pasar malam, pentas seni, dan turnamen adalah beberapa contoh kongret pencitraan yang dijadikan daya tarik untuk masyarakat luas. Walaupun pada kenyataannya perannya tidak berpengaruh pada nilai kesakralan dan spiritual yang terkandung dalam ritual upacara adat Rebo Pungkasan.

Rebo Pungkasan merupakan salah satu contoh upacara adat yang teridentifikasi dengan beberapa kejanggalan yang muncul, jika diamati lebih luas kemungkinan akan kejangalan tersebut juga terjadi dalam upacara-upacara adat yang lainnya.

Selanjutnya, keaslian suatu upacara juga patut dipertanyakan. Ada kecenderungan kalau pemerintah berusaha membuat turis berlama-lama di negeri ini sehingga di buat event bersamaan dengan musim liburan (Lastoro, 2007:157). Pernyataan tersebut seperti sebuah rahasia umum yang dimiliki pemerintah. Semestinya masyarakat menjadikan hal tersebut sebagai media untuk berpikir bahwa ketika keyakinan spiritual tidak kuat, maka akan mudah goyah dan kalah dengan ide-ide kreatif yang dapat berkembang liar.

Pencitraan sudah merajalela dalam area ritual. Pada satu ruang lingkup upacara adat Rebo Pungkasan, pencitaan dapat dilihat jelas dalam lemper Boga Wiwaha. Hal tersebut seolah-olah seperti iklan di televisi, orasi pada kampanye, sosial media, dan sebagainya. Segalanya dikemas manis dan menarik, padahal dibalik itu semua terdapat kepalsuan dan kebohongan yang disembunyikan. Sesuatu yang disajikan/ditawarkan belum tentu sesuai dengan kenyataan yang terjadi. Sebuah pencitraan sama halnya dengan sebuah topeng yang menjadi penutup citra yang sesungguhnya.

Rebo Pungkasan ibarat sebuah "pakaian" yang dikenakan oleh masyarakat Wonokromo, terkesan hanya digunakan sebagai identitas masyarakat setempat agar citra daerah baik dimata pemerintah maupun wisatawan. Pencitraan seperti halnya seseorang yang berbudaya Jawa tetapi tidak dapat menempatkan sikap sebagai orang Jawa. Orang jawa mengatakan wong Jawa ilang Jawane.

Bahasa iklan sangat kental sekali dengan sebuah pencitraan. Segala keunggulan ditawarkan dengan sedemikian rupa. Bahasa yang disampaikan dihiperbolakan sehingga 
menarik pehatian khalayak ramai. Hal tersebut pengingatkan pada fenomena-fenomena kecil yang terjadi namun sangat menarik untuk dibahas. Sebelum rentetan upacara adat Rebo Pungkasan diadakan, biasanya sudah mulai terdengar, dalam bahasa jawa disebut Gethok Tular. Informasi yang tentang dilaksanakannya upacara adat semakin hari semakin tersebar dari mulut ke mulut bahkan poster besar mulai ditempel dibeberapa perempatan jalan. Bahasa iklan sudah terasa. Bahkan dalam informasi verbalpun tersirat sebuah bahasa hiperbola tentang upacara Adat. Misalnya saja kata ritual sakral. Dibenak peneliti, sesuatu yang dikatakan ritual sakral adalah sesuatu yang dilakukan secara berulang-ulang dengan 'nilai spiritual dan kesakralan' yang kuat dan terkandung di dalamnya.

\section{Kesimpulan}

Rebo Pungkasan adalah hari yang dipercaya akan turunnya banyak malapetaka. Pada hari itu juga kyai welit memberikan doa pada air yang dibuang di tempuran kali Opak dan Kali Gajah Wong. Selain untuk memperingati hal tersebut, masyarakat Wonokromo juga berharap selalu terbebas dari malapetaka oleh karena itu diadakannya Upacara adat Rebo Pungkasan.

Seiring berjalannya waktu, ide-ide kreatif banyak muncul dikalangan muda. Sehingga seakan-akan upacara adat dikemas dengan tujuan lain. Lemper raksasa seolaholah hanya sebuah pencitraan. Hal tersebut terbukti dengan temuan bahwa lemper yang digunakan sebagai icon upacara hanyalah sebuah replika. Diadakannya turnamen, pentas seni, lomba-lomba, pasar malam, dll membuat image upacara adat Rebo Pungkasan seakan-akan sebagai pesta rakyat atau pertunjukan bukan ritual upacara adat.

Rasa khusuk, sakral, dan khidmat hampir hilang termakan oleh uforia yang ada. Upacara adat Rebo Pungkasan seolah-olah sebagai sarana pencitraan masyarakat. Apalagi sekarang ini semakin banyak masyarakat yang membatasi diri dengan hal-hal yang bersifat tradisional, akibatnya sekarang ini terjadi perubahan budaya terlebih pada pandangan tentang nilai. Sehingga, makna upacara adat kurang dapat diserap dengan baik.

Rebo Pungkasan merupakan salah satu contoh upacara adat yang teridentifikasi dengan beberapa kejanggalan yang muncul, jika diamati lebih luas kemungkinan akan kejangalan tersebut juga terjadi dalam upacara-upacara adat yang lainnya.

\section{Kepustakaan}

Berger, Arthur. 2000. Tanda-tanda dalam Kebudayaan Kontemporer. Yogyakarta : Tiara Wacana.

Featherstone, Mike. 2008. Postmodernisme dan Budaya Konsumsi. Yogyakarta : Pustaka Pelajar.

Griffin, David. 2005.Visi-visi Postmodern. Yogyakarta : Kanisius.

Herusatoto, Budiono. 2001. Simbolisme dalam Budaya Jawa. Yogyakarta : Hanindita.

Horikoshi, Hiroko. 1987. Kyai dan Perubahan Sosial. Jakarta : PT. Temprint.

Junaedi, Deni. 2016. Estetika Jalinan Subjek, Objek, dan Nilai. Yogyakarta : Artciv

Koentjaraningrat. 2009. Pengantar Ilmu Antropologi. Jakarta : Rineka Cipta. 
Galih Puspita Karti, INDIKASI PENCITRAAN DALAM UPACARA ADAT ...

Lastoro, Lono Dkk. 2007. Jagad Upacara. Yogyakarta : Ekspresibuku.

MH, Yana. 2012. Falsafah dan Pandangan Hidup orang Jawa. Yogyakarta: Bintang Cemerlang.

Murianto, Dwi. 2015. Art \& Levitation. Yogyakarta : Pohon cahaya.

Poerwadarminta, WJS. 2007. Kamus Umum Bahasa Indonesia. Jakarta: Balai Pustaka.

Sairin, Sjafri. 2002. Perubahan Sosial Masyarakat Indonesia. Yogyakarta : Pustaka Pelajar.

Sarjiwo. 2008. Panggung. Bandung: UPT Puslimas.

Sumardjo, Jakob. 2006. Estetika Paradog. Bandung : Sunan Ambu Press.

Sunaryadi. 2013. Filsafat Seni. Yogyakarta : Lintang Pustaka Utama.

Twikromo, Argo Dkk. 2010. Pencitraan Adat Menyikapi Globalisasi. Yogyakarta : PSAP UGM. 